\title{
IMPLEMENTASI KEPEMIMPINAN DALAM PENINGKATAN SISTEM PENJAMINAN MUTU INTERNAL PADA SEKOLAH TINGGI AGAMA ISLAM KHARISMA CICURUG SUKABUMI
}

\author{
MUHAMMAD ADLAN NAWAWI \\ Institut PTIQ jakarta \\ adlannawawi@ptiq.ac.id \\ RUDINI \\ Pascasarjana Institut PTIQ Jakarta \\ Rudiniflorezi7@gmail.com
}

\begin{abstract}
ABSTRAK
Implementasi Kepemimpinan Dalam Peningkatan Sistem Penjaminan Mutu Internal Pada Sekolah Tinggi Agama Islam Cicurug-Sukabumi, Jurnal: Program Studi Magister Manajemen Pendidikan Islam Institut Perguruan Tinggi Ilmu Al-Qur'an (PTIQ) Jakarta. Penelitian ini bertujuan untuk mengetahui data-data empirik terkait dengan Implementasi Kepemimpinan Sistem Penjaminan Mutu Internal Pada Sekolah Tinggi Agama Islam Cicurug-Sukabumi. Dalam penelitian tesis ini merupakan penelitian lapangan, dengan pendekatan kualitatif, yaitu sebuah metode untuk memperoleh suatu gambaran mengenai keadaan, gejalah, atau respon suatu kelompok tertentu. Teknik pengumpulan data menggunakan observasi, wawancara dan dokumentasi. Teknik analisa data yang di gunakan menggunakan model analisis deskriptif. Jenis analisis yang digunakan adalah analisa secara sistematis data yang diperoleh dari hasil wawancara, catatan lapangan, dan dokumentasi, dengan cara menjabarkan terkait menjawab permasalahan implementasi kepemimpinan dalam peningkatan sistem penjaminan mutu internal pada kampus Sekolah Tinggi Agama Islam Kharisma Cicurug-Sukabumi dan membuat kesimpulan dijabarkan secara deskriptif. Hasil penelitian ini menunjukkan bahwa: Pertama, hambatan-hambatan terkait dalam peningkatan mutu internal yakni; Dana Terbatas, sarana dan prasarana tidak terpenuhi, lemahnya sumber daya manusia, belum optimalnya kinerja tenaga pendidik dan kependidikan, manajemen perguruan tinggi belum tertata dengan baik dan rendahnya mutu lulusan perguruan tinggi; Kedua, upaya ketua STAI Kharisma Sukabumi di antaranya yaitu: memperkuat sumber daya tenaga kependidikan, Pendidikan dan pelatihan dalam pengelolaan penjaminan mutu, pendidikan dan pelatihan dalam pengelolaan penjaminan mutu, Memberikan suport kelompok kerja meraih mutu, dan mensosialisasikan teknik dalam perbaikan mutu; Ketiga, Implementasi kepemimpinan dalam peningkatan sistem penjaminanan mutu internal belum dijalankan secara baik karena masih lemahnya komitmen pengelola kepemimpinan untuk mencapai keunggulan mutu. Selain itu kurangnya kecakapan pengelola STAI Kharisma Cicurug-Sukabumi dengan spektrum tugas maupun masalah pendidikan yang semakin kompleks.
\end{abstract}

Kata kunci: Kempemimpinan, dan Sistem Penjaminan Mutu Internal. 


\begin{abstract}
Implementation of Leadership in Improving the Internal Quality Assurance System at the Islamic College of Cicurug-Sukabumi, Thesis: Study Program of Master in Islamic Education Management of the Institute of Al-Qur'an Science (PTIQ) Jakarta. This study aims to determine empirical data related to the Leadership Implementation of the Internal Quality Assurance System at the Islamic College of Cicurug-Sukabumi. This thesis research is a field research using a qualitative approach, which is a method to obtain an illustration of the circumstances, symptoms, or responses of a particular group.Data collection techniques used observation, interviews, and documentation. The data analysis technique used descriptive analysis model. The type of analysis used is a systematic analysis of data obtained from interviews, field notes, and documentation, by elaborating in relation to respond the problem of leadership implementation in improvin the internal quality assurance system at the Kharisma Islamic College of Cicurug-Sukabumi and made conclusions outlined on a descriptive basis.Results of this study indicate that: First, leadership has not served or been well-organized in terms of procurement of facilities and infrastructure, human resources do not support, the performance of and education has not been optimal, the college management not been well-organized and the quality of college graduates is low; Second, the head of STAI Kharisma Sukabumi has made efforts related to the optimal performance of the teaching and educational staffs, including; strengthening the resources of education personnel, education and training in managing quality assurance, providing support for working groups to achieve quality and disseminating techniques in improving quality; Third, College management has not been well organized because of the weak commitment leadership managers to achieve quality excellence. In addition, the lack of management skill of STAI Kharisma Cicurug-Sukabumi with an increasingly complex spectrum of tasks and educational problems.
\end{abstract}

Keywords: Leadership and Internal Quality Assurance System. 


\section{A. PENDAHULUAN}

Globalisasi menjadi tantangan tersendiri bagi perguruan tinggi, Kepemimpinan merupakan unsur strategis dalam suatu perguruan tinggi, kepemimpinan dapat dilihat dari sudut individu, proses, maupun efeknya terhadap organisasi. Peran kepempinan dapat mendorong perubahan organisasi. Dalam hubungannya dengan organisasi perguruan tinggi, rektor pada tingkat universitas, dekan dalam tingkatan fakultas dan kajur/kaprodi pada tingkat program studi merupakan pemimpin yang amat berperan dalam menentukan kinerja organisasi perguruan tinggi melalui upaya pergerakan dan pengarahan pada seluruh anggota organisasi menjalankan peran dan dan tugasnya secara efektis. Untu itu kepemimpinan pendidikan perguruan tinggi menjadi faktor yang urgen bagi upaya mengembangkan organisasi yang bermutu. ${ }^{1}$

Di era globalisasi dan modernitas saat ini, peningkatan mutu pendidikan kiranya menjadi masalah yang urgen. Peningkatan mutu pendidikan diperlukan dalam pengelolaan organisasi pendidikan agar bergerak menuju satu arah. Pendidikan yang baik dan bermutu menjadi dasar pengembangan dan kemajuan selanjutnya. Oleh karena itu, pengelolaan berbagai kebijakan pemerintah dan keinginan masyarakat dalam kerangka perbaikan mutu dengan kreativitas, inovasi yang tinggi, dan strategi manajemen yang baik dalam konteks sistem. Sehingga akan tercipta pendidikan yang lebih baik dan lebih maju untuk bersaing ditingkat regional, nasional, dan global. ${ }^{2}$

Dunia kita semakin sempit. Pergaulan dan hubungan antar bangsa semakin erat sudah merupakan kenyataan, baik dalam politik, ekonomi, sosial dan kebudayaan. Arus ini semakin akan semakin kuat sejalan dengan meningkatnya taraf hidup dan perkembangan manusia itu sendiri, yang akan membawa kepada kesadaran yang lebih meningkat terhadap hak dan kewajiban manusia terhadap dirinya, masyarakat bangsa, dan masyarakat dunia. Hubungan antarsesama manusia yang dekat akan menumbuhkan perasaan ingin sederajat dalam kehidupan antarnegara. Oleh sebab itu, arus globalisasi menuntut pengembangan manusia bermutu. Pendidikan yang bermutu adalah moto dari arus globalisasi. ${ }^{3}$

Pada sektor pendidikan, globalisasi dan pasar bebas berdampak pada berbagai jenjang pendidikan mulai dari pendidikan dasar, pendidikan menengah maupun ppendidikan tinggi. Sektor pendidikan tidak hanya memikirkan perkembangan skala lokal dan nasional. Namun terpacu untuk berkembang

${ }^{1}$ Uhar Suharsaputra, Manajemen Pendidikan Perguruan Tinggi: Strategi Menghadapi Perubaha (Bandung: PT Refika Aditama, 2015), 357.

${ }^{2}$ Nur Zain, Gerakan Bermutu Pendidikan: Teori dan Aplikasi (Jogjakarta: Ar-Ruzz Media, 2016), 5.

${ }^{3}$ H.A.R. Tilaar, Manajemen Pendidikan Nasional: Kajian Pendidikan Masa Depan (Bandung: PT Remaja Rosdakarya, 2011), 156. 
mengikuti standar internasional. ${ }^{4}$ Dalam konteks pendidikan tinggi, globalisasi diterjemahkan sebagai kebebasan dalam mengatur operasionalisasi di perguruan tinggi. Kebebasan yang dimaksud mencakup penentuan sistem penjaminan mutu yang paling sesuai agar proses yang berlansung di perguruan tinggi mampu memenuhi standar Internasional. Perguruan tinggi diberi kebebasan sendiri karena karakteristik yang dimiliki setiap perguruan tinggi berbeda-beda. ${ }^{5}$

Secara global, permasalahan pendidikan tersebut dapat diiventarisasi menjadi beberapa tantangan besar yang kompleks. Pertama, tantangan untuk meningkatkan nilai tambah dalam rangka meningkatkan prokduktivitas, pertumbuhan dan pemerataan ekonomi, sebagai upaya untuk memelihara dan meningkatan pembangunan yang berkelanjutan. Kedua, tantangan untuk melakukan pengkajian secara komprehensif dan mendalam terhadap terjadinya ttansformasi (perubahan) struktur masyarakat, dari masyarakat yang agraris ke masyarakat industri yang mengusai teknologi dan informasi, yang implikasinya sumber daya manusia (SDM). Ketiga, tantangan dalam persiapan global yang semakin ketat, yaitu bagaimana meningkatkan daya saing bangsa dalam meningkatkan karya-karya yang bermutu dan mampu bersaing sebagai hasil penguasaan ilmu pengetahuan, teknologi, dan seni (Ipteks). ${ }^{6}$

Dalam konteks keindonesiaan tujuan pendidikan nasional dalam tujuan pendidikan nasional yang tertuang dalam tujuan dan fungsi pendidikan nasional yang tertuang dalam Undang-Undang Sistem Pendidikan nasioanl Nomor 20 Tahun 2003, "Pendidikan nasional berfungsi mengembangkan kemampuan dan membentuk watak serta peradaban bangsa yang bermartabat dalam rangka mencerdaskan kehidupan bangsa, bertujuan untuk berkembangnya potensi peserta didik agar manusia yang beriman dan bertakwa kepada Tuhan Yang Maha Esa, berahklak mulia, sehat, berilmu, cakap, kreatif, mandiri, dan menjadi warga warga negara yang demokratis serta bertanggung jawab". ${ }^{7}$ Implikas dari dari harapan itu menuntut manusia berkualitas untuk manusia senantiasa mandiri yang dilandasi keimanan dan ketakwaan kepada Tuhan Yang Maha Esa serta mampu untuk memberikan kontribusi dalam mewujudkan terciptanya masyarakat adil dan sejahtera.

4 Saihu, "Implementasi Manajemen Balanced Scorecard di Pondok Pesantren Jam'iyyah Islamiyyah Tangerang Selatan, Mumtaz, Vol. 3, No. 1 (2019): 1-22.

${ }^{5}$ Indriana Lestari, "Pengaruh Sistem Penjaminan Mutu Internal Dan Sistem Manajemen ISO 9001:2008 Terhadap Kinerja Universitas Katolik Indonesia Atma Jaya Jakarta", TESIS. Jakarta: Fakultas Ilmu Sosiall Dan Ilmu Politik Progaram Pasca Sarjana, 2012, 1.

${ }^{6}$ Arbangi, et.al., Manajemen Mutu Pendidikan (Depok: Kencana, 2018), VI.

7 Undang-Undang 20 Tahun 2003, Tentang Sidiknas (Sistem Pendidikan Nasional) Beserta Penjelasannya (Bandung: Fokus Media, 2003), 7. 
Salah satu tantangan penting yang dihadapi perguruan tinggi ataupun universitas adalah bagaimana mengelola sebuah mutu. ${ }^{8}$ Terutama sekali dalam dunia persaingan global dan industri massal. Di dalam dunia industri bisnis, mutu adalah adalah nilai jual yang menjadi prioritas utama. Mutu menjadi satu-satunya faktor pembeda yang dibutuhkan oleh konsumen. Kendati demikian, mutu tidak hanya ada dalam institusi industri tetapi juga menjadi kebutuhan institusi pendidikan. Hal ditujukan agar institusi mampu mendidik akademisi-akademisi dengan reputasi yang positif.

Hal ini perlu mendapatkan perhatian sungguh-susngguh karena kesenjangan akan semakin parah dan semakin besar apabila tidak segera ditanggulangi. Di dalam proses ini peranan penting pendidikan menjadi sangat menentukan karena pendidikan itu mendorong terjadinya adopsi atau transfer teknologi, adaptasi teknologi maupun penyebarannya. Untuk menjadi bangsa yang maju, pendidikan menjadi faktor utama yang memiliki faktor utama yang memiliki sumber daya manusia yang berkualitas dan tidak mudah diperbudak oleh pihak lain. Pendidikan merupakan kebutuhan utama bagi bangsa ingin maju, berkembang, dan berdaya saing pada tataran global. Peningkatan mutu pendiidkan menghasilkan sumber daya manusia yang andal, sangat berpengaruh terhadap kemajuan suatu bangsa. ${ }^{9}$

Harapan utama pendidikan perbaikan mutu sebagai suatu sistem yang mencakup pengelolaan pendidikan dalam ranah mewujudkan hasil penyelenggaraan pendidikan yang dapat memberikan kontribusi pembangunan peradaban manusia di masa depan, khususnya di wilayah kesatuan Republik Indonesia. Melalui peningkatan mutu di harapkan dapat menghadapi berbagai tantangan internal maupun eksternal, sehingga diperoleh model pendidikan yang solid, reliabel, dan akuntabel. Tantangan eksternal yang meliputi, dimensi sosial, politik, ekonomi, budaya. Tantangan internal yang berhubungan dengan yang tertera dalam delapan standar pedidikan, yakni kompetensi lulusan, Isi, Proses, Pendidikan dan Tenaga kependidikan, Sarana dan Prasarana, pengelolaan, Pembinyaan Pendidikan, dan Penilaian. ${ }^{10}$

Pendidikan di tanah air sejauh ini belum berhasil menyediakan insan yang berkualitas yang siap untuk mengisi dan menggerakan pembangunan. ${ }^{11}$ Belajar dari sejarah bangsa-bangsa di muka bumi, kita dapat menarik sebuah kesimpulan bahwa bangsa yang maju dalam berbagai bidang, ternyata bukanlah bangsa yang memiliki kelimpahan sumber daya alam, melainkan bangsa yang memiliki sumber daya manusia yang berkualitas. Tidak dapat disangkal bahwa kualitas sumber daya manusia suatu bangsa merupakan hasil dari pendidikan bermutu, sayangnya,

${ }^{8}$ Edward Sallis, Manajemen Mutu Pendidikan, diterjemahkan oleh Ahmad dan Fahrurrozi dari judul Total Quality Management In Education (Jogjakarta: IRCiSoD, 2012), 21.

${ }^{9}$ H.A.R. Tilaar, Manajemen Pendidikan Nasional: Kajian Pendidikan Masa Depan, 156.

${ }^{10}$ Arbangi, dkk., Manajemen Mutu Pendidikan, V.

${ }_{11}$ Willy Susilo, Starategi Menegakkan Mutu Pendidikan Tinggi Berbasis KKNI (Yogyakarta: ANDI OFFSET, 2018), 2. 
pendidikan bermutu tidak datang dengan sendirinya, melainkan hasil pemikiran komprehensif dan mendalam yang dituangkan dalam sebuah rancang bangun dalam kerangka sistem pendidikan nasional, diimplementasikan dan terus ditingkatkan secara berkelanjutan.

Perguruan tinggi sebagai penyelenggara pendidikan tinggi tentu tidak bisa mengabaikan perubahan yang terjadi, model manajemen menajemen kovensional, bersifat rutin dan fokus pada pengeloalaan interaksii pada pendidik dan tenaga kependidikan, perlu mendapatkan pengembangan baru dalam memperkuat organisasi pendidikan (perguruan tinggi), agar lebih mampu beradaptasi dengan perubahan serta meresponnya dengan tepat, cepat, akurat dan cerdas, sehingga perubahan yang terjadi dapat pemicu dan pemacu perkembangan serta perkembangan perguruan tinggi dalam menyelenggarakan pendidikan tinggi (Tridharma) agar lebih efektif, efisien dan bermutu. ${ }^{12}$

Pelaksanaan Penjaminan mutu pendidikan pada suatu Perguruan Tinggi bertujuan untuk memelihara dan meningkatkan mutu penyelenggara Tri Dharma Perguruan Tinggi yang berstandar secara berkelanjutan. Pejaminan mutu pendidikan tinggi merupakan program yang penting dan wajib dilaksanakan oleh semua intitusi penyelenggara pendidikan tinggi berdasarkan Undang-undang Nomor 12 tahun 2012 tentang Pendidikan Tinggi yang mengamanatkan bahwa Perguruan Tinggi harus melaksanakan dan implementasikan sistem penjamin mutu sebagai aspek yang menentukan untuk meningkatkan daya saing Perguruan Tinggi. ${ }^{13}$

Regulasi pendidikan Tinggi di tanah air terus bertambah dan terus berubah. Pertanyaannya, apakah semakin banyak regulasi semakin baik, dan semakin mendorong perguruan tinggi mau dan mampu menegakkan mutu pendidikan? Apakah berbagai perubahan regulasi yang dilakukan sudah dipikirkan secara komprehensif dan mendalam sehingga menghasilakan imbas positif? Faktanya, lebih banyak perguruan tinggi yang tidak mampu menjalankan regulasi secara efektif, dibandingkan yang mau dan mampu melaksanakannya secara taat dan simalakama, dilaksanakan memberatkan, tidak dilaksanakan menakutkan.Ujungujungnya regulasi hanya menjadi pelengkap penderita, diakal-akali agar terkesan dijalankan. ${ }^{14}$ Regulasi bidang pendidikan yang mengatur tentang mutu perguruan tinggi sudah tercantum dalam Standar Nasional Pendidikan Tinggi (SNPT), Permenristekdikti No. 44 tahun 2015, yang meliputi Standar Nasioanal Pengabdian Kepada Masyarakat sebagai acuan dalam pelaksanaan Tridharma perguruan tinggi.

${ }_{12}$ Uhar Suharsaputra, Manajemen Pendidikan Perguruan Tinggi: Strategi Menghadapi Perubahan, V.

${ }_{13}$ Tutut Suryanigsih dan Ali Imron, Komitmen Kepemimpinan Dalam Implementasi Sistem Penjaminan Mutu Akademik Perguruan Tinggi: Studi Kasus Pada STKIP PGRI Tulungagung", Jurnal Pejaminan Mutu, Vol. 05 No. 1 (2019): 110.

${ }_{14}$ Willy Susilo, Starategi Menegakkan Mutu Pendidikan Tinggi Berbasis KKNI (Yogyakarta: ANDI OFFSET, 2018), 19. 
SNPT mengatur secara komprehensif pendidikan tinggi di Indonesia melalui penetapan sejumlah standar.

Untuk pengendalian dan pengawasan penerapan SNPT juga sudah ada sistem penjamin mutu pendidikan pendidikan tinggi (SPM DIKTI), yakni SPMI (sistem penjaminan mutu internal) yang dilaksanakan secara otonom oleh perguruan tinggi, dan akreditasi program studi dan institusi perguruan tinggi mengunakan skema SMPE (sistem penjaminan Mutu Eksternal) oleh Badan Akreditasi Nasional Pendidikan Tinggi (BAN PT) yang melalukan kelayakan dan tingkat pencapaian mutu program studi dan perguruan tinggi. ${ }^{15}$ Namun persoalanya, dalam pelaksanaan SPMI masih terjadi kesalahan atau ketidaksempurnaan dalam hal, mulai dari hal kecil sampai hal yang besar, mulai dari kesalahan di tataran falsafah, konsep, sistem sampai teknik Pelaksanaan, baik yang dilakukan oleh personil prodi dan perguruan Tinggi.

Dalam pandangan Akhmad Shunhaji dalam bukunya, yang mengutip pemikiran Abdul Haris dan Nurhayati memandang bahwa masalah besar dalam pendidikan Indonesia adalah rendahnya mutu pendidikan yang dipengaruhi oleh perspektif makro yang menyangkut masalah kurikulum, kebijakan pendidikan, kualitas pendidikan, aplikasi teknologi informasi dan komunikasi dalam kegiatan belajar mengajar, biaya pendidikan dan manajemen profesional. ${ }^{16}$ Dengan demikian, agar berjalanya suatu pendidikan bermutu tentu membutuhkan sosok pemimpin yang handal, sehingga diharapkan mampu meningkatkan kualitas di perguruan tinggi dengan memperhatikan butir-butir antara lain; kurikulum program studi, sumber daya manusia (dosen dan tenaga penunjang), mahasiswa proses pembelajaran, sarana dan prasarana, suasana akademik, keuangan, penelitian, dan publikasi, pengabdian kepada masyarakat, tata pamong, manajemen lembaga, system informasi, serta kerjasama dalam dan luar negeri. ${ }^{17}$

Berdasarkan uraian di atas, kepemimpinan mutu perguruan tinggi penting mendapat perhatian khusus karena melalui kepemimpinan tersebut dapat menumbuhkan sikap komitmen secara bersama-sama dalam merealisasikan pengembangan mutu perguruan tinggi. Untuk itu penelitian ini membantu dalam mengantarkan pada horizon dalam meningkatkan pendidikan tinggi dengan mengintegrasikan berbagai aspek dan bidang yang perlu oleh pemimpin yang mampu mengelolah dengan tepat, adaptif, kreatif, inovatif, karena perguruan tinggi sekarang ini ditempatkan dan bertempat dalam perubahan yang cepat. Agar upaya peningkatan mutu pendidikan tinggi dapat berjalan efektif dan mencapai tujuan

${ }_{15}$ Willy Susilo, Starategi Menegakkan Mutu Pendidikan Tinggi Berbasis KKNI, 19.

16 Ahkmad Shunhaji, Implementasi Pendidikan Agama di Sekolah Katolik Blitar dan Dampaknya Terhadap Interaksi Sosial (Yogyakarta: Aynat Publishing, 2017), 40.

${ }_{17}$ Tutut Suryanigsih dan Ali Imron, "Komitmen Kepemimpinan Dalam Implementasi Sistem Penjaminan Mutu Akademik Perguruan Tinggi: Studi Kasus Pada STKIP PGRI Tulungagung", Jurnal Pejaminan Mutu, Vol. 05 No. 1 (2019): 110. 
sesuai dengan cita-cita pendidikan nasional, maka diperlukan strategi yang tepat dan melakukan peningkatan mutu pendidikan pada semua bidang.

\section{B. METODE}

Tulisan ini menggunakan metode kualitatif. Menurut Sugiyono, metode penelitian kualitatif adalah metode penelitian yang digunakan untuk meneliti pada kondisi objek alamiah dimana peneliti adalah sebagai instrument kunci, teknik pengumpulan data dilakukan secara gabungan, analisis data bersifat induktif, dan hasil penelitian kualitatif lebih menekankan makna dari pada generalisasinya. Sedangkan jenis penelitian yang dipakai oleh peneliti adalah jenis deskriptif. Penelitian deskriptif kualitatif ditujukan untuk mendeskripsikan dan menggambarkan fenomena-fenomena yang ada, baik bersifat alamiah maupun rekayasa manusia, yang lebih memperhatikan mengenai karakteristik, kualitas, keterkaitan antar kegiatan. ${ }^{18}$

Selain itu, Penelitian deskriptif tidak memberikan perlakuan, manipulasi atau pengubahan pada variabel-variabel yang diteliti, melainkan menggambarkan suatu kondisi yang apa adanya. Satu-satunya perlakuan yang diberikan hanyalah penelitian itu sendiri, yang dilakukan melalui observasi dan wawancara. Pendekatan ini digunakan untuk memperoleh gambaran sistem penjaminan mutu di STAI Kharisma Sukabumi dalam perspektif keuangan, perspektif pelanggan, perspektif proses bisnis internal, perspektif pembelajaran dan pertumbuhan.

\section{HASIL DAN PEMBAHASAN}

Salah satu acuan indikator keberhasilan kepemiminan diukur dari mutu pendidikan yang ada di lembaga yang dipimpinnya. Dalam konteks pendidikan, pengertian mutu mencakup input, proses, dan output pendidikan. Input pendidikan adalah segala sesuatu yang harus tersedia karena dibutuhkan untuk berlangsungnya proses. Proses pendidikan merupakan berubahnya sesuatu menjadi sesuatu yang lain dengan mengintegrasikan input perguruan tinggi, sehingga mampu menciptakan situasi pembelajaran yang menyenangkan, motivasi dan minat belajar yang tinggi. Output pendidikan merupakan kinerja institusi yang dapat diukur dari kualitasnya, produktivitasnya, efisiensinya, inovasinya, dan moral kerjanya. Dalam konsep yang lebih luas, mutu pendidikan mempunyai makna sebagai suatu kadar proses dan hasil pendidikan secara keseluruhan yang ditetapkan sesuai dengan pendekatan dan kriteria tertentu.

Temuan Pelaksanaan sistem penjaminan mutu internal STAI Kharisma berdasarkan data empirik yang ditemukan maka dapat diketahui terdapat beberapa pokok persoalan yang dapat menghambat keberhasilan perguruan tinggi. tentunya ada beberapa hal yang penghambat tegaknya mutu pedidikan sebagai berikut:

18 Sugiyono, Metode Penelitian Pendidikan: Pendekatan Kuantitatif, Kualitatif, Dan $R$ \& $D$ (Bandung: ALPABETA, 2010), 9. 
1. Rendahnya mutu publikasi hasil penelitian

Salah satu permasalahan yang menghambatnya dalam peningkatan mutu, adalah publikasi hasil penelitian belum dijalan secara baik, sebagaimana dari hasil wawancara saya dengan Kabag tata usaha STAI Kharisma Sukabumi sebagai berikut:

"Publikasi hasil penelitian di STAI Kharisma ini belum optimal. Untuk publikasi hasil penelitian di STAI masih ditingkat lokal, yakni STAI baru menghasilkan jurnal yang disebut Aktualisasi Nilai Pendidikan Islam (ANPI). Jurnal ini dipublikasi melalui web STAI Kharisma." 19

Dalam hal ini juga dinyatakan oleh Ketua STAI terkait publikasi hasil penelitian bahwa: "Publikasi hasil penelitian di sini, masih bersifat lokal belum taraf nasional ataupun internasional, dan kami melakukan publikasi melalui facebook, whatapp dan lain-lain." 20

Dalam permasalahan di atas, untuk menjalankan manajemen mutu yang benar memang tidak mudah. Manajemen mutu yang sungguh-sungguh bermutu harus dikembangkan dengan tujuan yang jelas, di atas landasan falsafah yang benar, dan konsep diinternalisasikan secara berkelanjutan, sehingga dipahami secara mendalam dan luas oleh segenap civitas akademika. Dengan hal ini, sudah seharusnya kepemimpinan lebih bijak dalam menyikapi permasalahan tersebut. Sehingga mutu dalam bidang publikasi hasil penelitian meningkat. Baik taraf lokal, nasional atau pun internasional.

\section{Dana Terbatas}

Pendidikan yang bermutu tidaklah murah. Perguruan tinggi yang hanya mengandalkan sumber kuliah akan sulit untuk menegakkan mutu pendidikan secara maksimal. Persoalan dana, tidak bisa dipungkiri, merupakan persoalan yang paling dominan menghambat untuk membangun mutu. Tidak sedikit perguruan tinggi terutama PTS papan bawah, yang terjebak dalam kesulitan dana sehingga terpaksa menjalankan tridharma perguruan tinggi dengan kondisi apa adanya yang serba kekurangan (khususnya STAI Kharisma). Peneliti wawancara bersama ketua STAI Kharisma Cicurug Sukabumi, yaitu Dr. Ujang Saefullah, ia mengatakan "salah satu penghambat dalam peningkatan mutu (SPMI) adalah dana terbatas." 21

Dalam konteks ini, biaya operasional untuk mengelola satu unit pendidikan tinggi dari waktu kewaktu terus meningkat. Pemerintah sejauh ini sudah banyak membantu, meskipun sangat terbatas. Tetapi persoalannya bukan

${ }_{19}$ Hasil Wawancara Dengan Ade Ismatullah, Kabag tata usaha STAI Kharisma CicurugSukabumi Tanggal 15 September 2019

20 Hasil Wawancara Dengan Bapak Ujang Saefullah, Ketua STAI Kharisma CicurugSukabumi Tanggal 15 September 2019

${ }^{21}$ Hasil Wawancara Dengan Bapak Ujang Saefullah, Ketua STAI Kharisma CicurugSukabumi Tanggal 15 September 2019. 
besar kecil-kecilnya anggaran, melainkan seberapa tepat pengalokasian anggaran terutama bidang pendidikan jangka pendek, menengah dan jangka panjang.

3. Kualitas SDM Rendah

Mutu sumber daya manusia (SDM) merupakan persoalan yang paling kritis dalam dunia pendidikan tinggi. pendidikan yang berorientasi pada penjaminan mutu memerlukan dosen sebagai pendidikan yang mampu menerapkan metode student centered learning, yakni pembelajaran yang fokus pada mahasiswa sebgai subyek pemberdayaan, bukan fokus pada darinya sebagai pengajar. Dalam hal ini peneliti wawancara bersama ketua STAI kharisma, yaitu bapak Bapak Ujang Saefullah, ia mengatakan pernyataannya, "Bahwa salah satu menghambatnya mutu internal STAI Kharisma rendahnya sumber daya manusia. Sehingga saya mengundang pemateri dari UIN Bandung untuk memberikan materi pada STAI Kharisma". ${ }^{22}$

Dengan hal tersebut di atas, ciri-ciri pendidikan yang paling utama adalah memiliki rasa tanggung jawab bukan pada ilmu yang diajarkan, melainkan tanggung jawab terhadap upaya pemberdayaan intelektual dan berlandaskan pada nilai-nilai kebenaran dan kejujuran. Tenaga kependidikan merupakan peran penting dalam membangun suasana kondusif melalui pelayanan akademik lancar dan tertib, tetapi juga menjadi inspirasi bagi peserta didik. Oleh karena itu, idealnya orang-orang yang bekerja di lingkungan institusi pendidikan, lebih lagi pendidikan tinggi, wajib memiliki pemahaman yang benar mengenai dunia pendidikan tinggi dan peran penting mereka dalam program besar membangun manusia.

\section{Kebutuhan Kompetensi Tidak Terpenuhi}

Kebutuhan kompetensi dunia kerja dari waktu ke waktu terus meningkat, dipicu oleh berbagai perubahan pada hampir semua bidang kehidupan. Kemajuan teknologi yang dimotori oleh pusat-pusat riset merupakan salah satu faktor yang telah mendorong ke arah perubahan industri dan perilaku dalam dunia usaha. Contohnya yang paling jelas adalah berkembangnya ilmu bisnis berbasis teknologi digital. Pada saat yang sama, kemajuan industri dan perubahan pola kegiatan usaha juga mendorong berkembangnya ilmu pengetahuan dan aplikasi teknologi baru. Implikasi dari perubahan yang terjadi secara timbal-balik itu adalah meningkatnya kebutuhan pada dunia kerja.

Dalam hal ini, kebutuhan Kompetensi di STAI Kharisma belum optimal memenuhi standar yang dibutuhkan dunia kerja, sebagaimana wawancara peneliti bersama mahasiswa Semester 5 (lima) STAI Kharima Sukabumi, ia mengatakan:"Salah satu permasalahan hambatnya mutu adalah kebutuhan

22 Hasil Wawancara Dengan Sukabumi Tanggal 15 September 2019.

Bapak Ujang Saefullah, Ketua STAI Kharisma Cicurug- 
kompetensi tidak mampu terpenuhi. ${ }^{23}$ Karena banyak juga mahasiswa setelah menganggur, bahkan lari ke kota mencari lapangan kerja.

Dengan hal ini, bila pendidikan tinggi STAI Kharisma Sukabumi tidak melakukan revitalisasi membangun kemampuan baru untuk menyesuaikan dengan perubahan dunia industri, usaha, dan ketenaga-kerjaan, serta tidak mampu memenuhi kebutuhan kompetensi untuk dunia kerja. Maka hal yang terjadi adalah ketertinggalan terus-menerus, dalam artian tidak mampu berdaya saing dalam globalisasi persaingan dunia kerja. Pendidikan merupakan persoalan kritis yang harus diletakkan sebagai persoalan dengan priritas tinggi, yang tepatnya harus dicarikan solusi. Dari mata kaca mata pendidikan, manusia berkualitas adalah mereka yang terdidik dan memiliki pengetahuan, keterampilan dan sikap yang membuatnya mampu menjadi insan yang tangguh, mandiri, beriman dan bertakwa kepada Tuhan Yang Maha Esa, berakhlak mulia, sehat cakap, kreatif mandiri, dan bertanggung jawab. Untuk membangun manusia berkualuitas mutlak diperlukan pendidikan, terutama pendidikan yang mengedepankan mutu. Pendidikan bermutu tidak serta merta tersedia dalam suatu bangsa dan negara, melainkan harus persiapkan, di kembangkan dan terus ditingkatkan bersama-sama melalui sinergi segenap pemangku kepentingan.

5. Sarana dan Prasarana tidak memadai

Setiap satuan pendidikan sudah selayaknya memiliki sarana dan prasarana demi menunjang pendidikan. hal ini berdasarkan peneliti temukan pada kampus STAI Kharisma ${ }^{24}$ dan juga sebagaimana dijelaskan oleh Miftahul Ulum saat wawancara bersama peneliti di kampus STAI Kharisma: "penghambat mutu pendidikan di STAI kami adalah di antaranya keterbatasan sarana dan prasarana tidak memadai." 25 Di anataranya: peralatan pendidikan kurang, media pendidikan, buku dan sumber belajar kurang memadai, dan juga prasarana yang meliputi lahan terbatas, ruang kelas, ruang pendidik, ruang laboratorium, ruang bengkel kerja, ruang unit produksi, ruang kantin, tempat olahraga, tempat ibadah, tempat lain yang di perlukan untuk menunjang proses pembelajaran yang teratur dan berkelanjutan."

Kondisi sarana prasarana kampus perguruan tinggi di STAI Kharisma Cicurug-Sukabumi melihat konteks di atas, masih banyak yang belum memadai untuk menunjang proses pembelajaran yang bermutu. Berdasarkan hal di atas, juga senada dikatakan oleh Annisa Nuraeni saat wawancara di kampus STAI Kharisma. Ia menyatakan: “Di kampus kami masih banyak kekurangan atau

${ }^{23}$ Hasil Wawancara Dengan Samsul, Mahasiswa STAI Kharisma Cicurug-Sukabumi Tanggal 15 September 2019.

${ }^{24}$ Hasil Observasi di Kampus STAI Kharisma Cicurug-Sukabumi, Tanggal 14 September 2019 Pukul 9.00.

${ }^{25}$ Hasil Wawancara Dengan Miftahul Ulum, mahasiswa STAI Kharisma Cicurug-Sukabumi Tanggal 15 September 2019. 
keterbatasan misalnya di antaranya; terbatasnya buku referensi yang dimiliki perpustakaan kampus, serta kurang memadainya, media pembelajaran, dan lainlain yang sangat diperlukan bagi keberlangsungan proses pembelajaran. Dalam hal ini juga termasuk konsep dan pengadaan alat alat komunikasi dan seperangkat komputer dan internet." ${ }^{26}$

\section{Belum Optimalnya Kinerja Tenaga Pendidik dan Kependidikan}

Pendidikan di STAI Kharisma jauh tertinggal oleh kampus-kampus lain yang disebabkan antara lain kinerja dan kemampuan serta kompetensi Sumber Daya Manusia Akademisi, hal ini wawancara peneliti dengan pimpinan STAI Kharisma seperti di bawah ini:“Di perguruan kami belum omptimal terkait kinerja Pendidik dan kependidikan diantaranya para dosen dan karyawan masih banyak yang belum memenuhi kompetensi dan kualifikasi yang sesuai dengan posisi dan jabatan yang diemban." ${ }^{27}$ Peran para dosen di Perguruan Tinggi sangat penting bagi kemajuan institusinya. Oleh karena itu pengembangan tenaga pendidik dan kependidikan sebagai unsur dominan dalam proses pembelajaran diarahkan untuk dapat meningkatkan kualifikasi, kompetensi, dan profesionalisme.

7. Manajemen Perguruan Tinggi Belum Tertata dengan Baik.

Masalah lain STAI Kharisma adalah terkait manajemen belum tertata dengan baik, berdasarkan wawancara peneliti bersama mahasiswa STAI Kharisma Cicurug Sukabumi sebagai berikut: “Masalah di Kampus ini, kurangnya pembenahan internal dan menata kembali pengelolaan organisasinya melalui perubahan paradigma, strategi, tata kelola, sistem dan prosedur, sampai kepada budaya organisasi, kompetensi dan gaya kerja pimpinan, struktural, dosen dan karyawannya." 28

Mengingat kompleksitas masalah di atas, maka yang harus dibenahi, dan menata ulang pengelolaan perguruan tinggi. Namun pembenahan ini harus dilakukan mengingat tantangan saat ini dan masa depan. Oleh karena itu perguruan tinggi dituntut untuk melaksanakan inovasi manajemen kelembagaan (institusi) pendidikan secara sistemik, total, dan mendasar dengan sasaran utamanya adalah perubahan orientasi, pandangan (visi), cara berpikir, dan pola perilaku nyata (action) sebagai manifestasi adanya perubahan orientasi

8. Belum optimal kualitas lulusan perguruan tinggi.

${ }^{26}$ Hasil Wawancara Dengan Annisa Nuraeni, Ketua STAI Kharisma Cicurug-Sukabumi Tanggal 15 September 2019.

${ }^{27}$ Hasil Wawancara Dengan Bapak Ujang Saefullah, Ketua STAI Kharisma CicurugSukabumi Tanggal 15 September 2019.

${ }^{28}$ Hasil Wawancara Dengan Nur Isna Saqinah, Mahasiswa STAI Kharisma CicurugSukabumi Tanggal 14 September 2019. 
Masalah lain yang terjadi di STAI Kharisma Cicurug-Sukabumi yaitu rendahnya kualitas, berdasarkan hasil wawancara peneliti bersama mahasiswa STAI Kharisma sebagaimana pernyataannya sebagai berikut: "Permasalahanyang saya lihat di lapangan adalah rendahnya kualitas lulusan perguruan tinggi dapat dilihat dari fenomena yang terjadi di masyarakat yaitu ilmu yang diperoleh dari perguruan tinggi kurang relevan dengan kebutuhan tenaga kerja yang diperlukan sehingga berdampak pada tingkat pengangguran intelektual, sebagian besar lulusan pendidikan tinggi hanya bisa menjadi buruh atau karyawan." 29

Lebih lanjut ia mengatakan bahwa persentasi lulusan di STAI Kharisma yang mampu menciptakan lapangan pekerjaan sendiri belum optimal. Penyebab Rendahnya Kualitas Lulusan Secara umum yang menjadi penyebab rendahnya kualitas lulusan dapat dilihat dari beberapa aspek yaitu: Pertama, Masukan (input) seperti, kurikulum perkuliahan yang berlaku di program Strata Satu (S1) kurang mengarah pada usaha mempersiapkan mahasiswa dapat terjun langsung ke masyarakat luas, dunia usaha maupun dunia industri. Banyak materi perkuliahan hanya berorientasi pada pengkajian dan pemahaman teori-teori yang kurang diimbangi dengan logika praktis yang terjadi di lapangan. Buku referensi yang digunakan oleh dosen kurang memberikan arahan kepada mahasiswa dalam menghadapi kondisi yang terjadi di dunia nyata. Bahkan mata kuliah yang bersifat praktis pun disampaikan secara teoretis sehingga tercipta suasana belajar yang kurang kondusif, ditambah kurangnya kelengkapan sarana prasarana pembelajaran, serta minimnya pelatihan tenaga pendidik dan kependidikan; Kedua, Proses penyelenggaraan perguruan tinggi; masih terdapat perguruan tinggi yang tidak sesuai dengan ketentuan, seperti: memadatkan waktu belajar, mengurangi frekwensi pertemuan/tatap muka.

\section{Upaya ketua STAI meningkatkan Mutu Sekolah Tinggi Agama Islam Kharisma}

Seorang pemimpin di perguruan tinggi memiliki tanggung jawab yang besar dalam menggerakkan seluruh sumber daya yang ada sebuah institusi, sehingga melahirkan etos kerja dalam mencapai tujuan. Di samping itu, kepemimpinan harus mampu menggerakkan orang lain secara sadar dan sukarela dalam melaksanakan kewajibannya secara baik sesuai dengan apa yang diharapkan pemimpin dalam mencapai tujuan. Kepemimpinan lemga kampus terutama ditujukan kepada para dosen, karena merekalah yang terlibat langsung dalam proses pendidikan.

Selain pemimpin perguruan tinggi dalam lembaga pendidikan, dosen juga memiliki peranan yang juga tak kalah penting terkait dengan peningkatan mutu pendidikan. Jika pemimpin adalah penentu kebijakan dalam lembaga, maka dosen adalah pelaksana dan orang yang terjun langsung dalam proses pendidikan yang berada dalam kelas.

${ }^{29}$ Hasil Wawancara Dengan Siti Ayi Syuroh, Mahasiswa STAI Kharisma Cicurug-Sukabumi Tanggal 15 September 2019. 
Adapun hasil yang diperoleh dari penelitian ini tentang upaya ketua STAI Kharisma Cicurug-Sukabumi30 dalam meningkatkan sistem penjaminan mutu internal sebagai berikut:

a. Memperkuat sumber daya tenaga kependidikan

Dalam rangka jangka panjang, ketua STAI meyatakan bahwa agenda utama adalah upaya memperkuat sumber daya tenaga kependidikan ialah dengan memperkuat sistem pendidikan dan tenaga kependidikan yang dimiliki keahlian. Keahlian baru itu adalah modal manusia dan memerlukan perubahan dalam sistem pembelajarannya, di antaranya yaitu: pertama, keahlian yang diperlukan untuk mencapai keberhasilan akan semakin tinggi dan berubah sangat cepat; kedua, keahlian yang dibutuhkan sangat tergantung pada teknologi dan inovasi baru, maka banyak dari keahlian harus dikembangkan dan dilatih melalui pelatihan dalam pekerjaan; ketiga, kebutuhan akan keahlian itu didasarkan pada individu.

b. Pendidikan dan pelatihan dalam pengelolaan penjaminan mutu.

Perwujudan mutu didasarkan pada keterampilan setiap pegawai dalam merencanakan, mengorganisasikan, membuat, mengevaluasi dan mengembangkan sebagaimana tuntutan pelanggan.

c. Memberikan suport kelompok kerja meraih mutu

Tim kerja sama modalnya utama meraih mutu. Mereka saling mendorong atau melakukan sinergi dari semua personal yang bekerja sama dalam bidang yang sehingga saling keterkaitan satukan visi misi yang telah ditentukan bersama.

d. Mensosialisasikan teknik dalam perbaikan mutu

Mensosialisasikan dalam mengoptimalkan strategi dasar agar dapat berhasil melakukan perbaikan mutu lulusan dan pelayan lembaga kampus STAI Kharisma Cicurug Sukabumi.

Dalam konteks ini, kepemimpinan STAI Kharisma Cicurug-Sukabumi harus melakukan pengelolaan dan pembinaan terhadap seluruh komponen institusi melalui kegiatan administrasi, manajemen dan kepemimpinan yang sangat tergantung pada kemampuan manajerial. Hasil penelitian ini, menunjukkan bahwa terdapat hubungan yang signifikan antara kemampuan manajerial ketua atau pimpinan secara bersama-sama dalam meningkatkan mutu.

Keterlibatan pemimpin dalam meningkatkan mutu pendidikan sangat penting karena dapat mempengaruhi berhasil pada mutu pendidikan itu sendiri. Secara garis besar, ruang lingkup ketua STAI dapat diklasifikasikan ke dalam dua aspek pokok, yaitu pekerjaan di bidang administrasi kampus dan pekerjaan yang berkenaan dengan pembinaan profesional kependidikan.

30 Hasil Wawancara Dengan

Bapak Ujang Saefullah, Ketua STAI Kharisma CicurugSukabumi Tanggal 15 September 2019. 


\section{Analisis Problematika kepemimpinan STAI dalam pelaksanaan mutu Pendidikan Tinggi dan upaya perbaikan Sistem Penjaminan Mutu Internal Perguruan Tinggi}

Problematika kepemimpinan dalam pelaksanaan mutu pendidikan STAI Kharisma Cicurug-Sukabumi. Berdasarkan hasil penelitian yang peneliti temukan dan sudah bahas di atas adalah Perencanaan yang dibuat oleh ketua STAI dalam pelaksanaan mutu pendidikan tersebut belum dijalankan secara optimal. Dalam konteks ini masih ditemukan beberapa kekurangan sebagaimana berikut:

Pertama, Rendahnya mutu publikasi hasil penelitian; ${ }^{31}$ Kedua, sarana dan prasarana belum terpenuhi; ${ }^{32}$ Ketiga, rendahnya sumber daya manusia; ${ }^{33}$ Keempat, belum optimalnya kinerja tenaga pendidik dan kependidikan; ${ }^{34}$ Kelima, manajemen perguruan tinggi belum tertata dengan baik; ${ }^{35}$ Keenam, belum optimalnya lulusan perguruan tinggi. ${ }^{36}$ Dengan melihat permasalahan di atas, seharusnya dalam proses pelaksanaan pendidikan, kegiatan kepemimpinan pendidikan secara otomatis melekat di dalamnya. Sebab pendidikan pada tingkat terbawah pun seperti anak usia dini (PAUD), memerlukan kepemimpinan untuk mengolah, mengatur, sekaligus memberdayakan lembaganya secara secara optimal. Apalagi sebuah lembaga perguruan tinggi yang mengedepankan pengembangan mutu mutlak sudah seharusnya ketua Sekolah Tinggi Agama Islam Kharisma (STAI) Cicurug Sukabumi memerlukan kepemimpinan yang berkualitas, cerdas, progresif, karakter dan memiliki kesiapan mental dan menghadapi persaingan secara global. Dalam konteks pendidikan, apabila seseorang mengatakan lembaga itu bermutu, maka bisa dimaknai bahwa lulusannya baik, gurunya baik, gedungnya baik dan sebagainya. ${ }^{37}$

Menurut Association of Supervision and Curriculum Developmen (ACSD), segaimana dikutip oleh Soemanto dalam bukunya, kepemimpinan pendidikan merupakan tidakan atau tingkah laku di antara individu-individu dan kelompokkelompok yang menyebabkan mereka bergerak ke arah tercapainya tujuan-tujuan pendidikan yang menambahkan penerimaan bersama bagi mereka. ${ }^{38}$ Dalam

31 Hasil Wawancara Dengan Ade Ismatullah, Kabag tata usaha STAI Kharisma CicurugSukabumi Tanggal 15 September 2019.

32 Hasil Wawancara Dengan Bapak Ujang Saefullah, Ketua STAI Kharisma CicurugSukabumi Tanggal 15 September 2019.

33 Hasil Wawancara Dengan Bapak Ujang Saefullah, Ketua STAI Kharisma CicurugSukabumi Tanggal 15 September 2019.

34 Hasil Wawancara Dengan Bapak Ujang Saefullah, Ketua STAI Kharisma Cicurug-

Sukabumi Tanggal 15 September 2019.

35 Hasil Wawancara Dengan Nur Isna Saqinah, Mahasiswa STAI Kharisma CicurugSukabumi Tanggal 14 September 2019.

${ }^{36}$ Hasil Wawancara Dengan Siti Ayi Syuroh, Mahasiswa STAI Kharisma Cicurug-Sukabumi Tanggal 15 September 2019.

37 Muhammad Fathurrohman dan sulistyorini, Implementasi Manajemen Peningkatan Mutu Pendidikan Islam: Peningkatan Lembaga Pendidikan Islam secara Holistik (Praktik dan Teoritik)..., hal. 41.

38 Soemanto dan Soetopo, Kepemimpinan dalam Pendidikan, Surabaya: Usaha Nasional 1982, hal. 18. 
padangan Nawawi yang dikutip oleh Marno, mendefinisikan kepemimpinan pendidikan adalah proses menggerakan orang-orang di dalam organisasi atau lembaga pendidikan tertentu untuk mencapai tujuan yang telah dirumuskan sebelumnya. Untuk mensukseskan proses kegiatan tersebut pemimpin dalam tiaptiap institusi pendidikan harus mampu bekerja sama dengan orang-orang yang dipimpinnya untuk memberikan motivasi agar melakukan pekerjaannya secara ikhlas. ${ }^{39}$

Dari uaraian di atas, kepemimpinan pada perguruan tinggi khususnya STAI Kharisma Cicurug-Sukabumi, seharusnya pada hakikatnya dapat dipahami sebagai upaya menggerakan sekolompok orang atau per individu dalam sebuah perguruan tinggi serta berani mengambil kebijakan pada perguruan tinggi yang dikelolanya. tentu harus ada langkah yang harus diperhatikan kepemimpinan mutu perguruan tinggi yang dalam hal ini STAI Kharisma Cicuru-Sukabumi. Yakni bagaimana implementasi kepemimpinan dalam penerapan ide-konsep, kebijakan, atau inovasi dalam suatu tindakan praktis, sehingga memberi dampak, baik berupa perubahan pengetahuan, keterampilan, maupu nilai atau sikap. ${ }^{40}$

Dalam pandangan Sudjana dalam bukunya, yang mengatakan implementasi dapat diartkan sebagai upaya pimpinan untuk memotivasi seseorang atau kelompok orang yang dipimpin dengan menumbukan, dorongan atau motivasi dalam dirinya untuk melakukan tugas atau kegiatan yang diberikan sesuai dengan rencana dalam rangka mencapai tujuan organisasi. ${ }^{41}$ Pelakasanaan merupakan hasil perencanaan dan pengorganisasian. Perencanaan dan pengorganisasian kurang bermakna dan efektif. Apabila tanpa tindakan kegiatan yang mendorong untuk melakasanakan kegiatan, implementasi (pelaksanaan) adalah salah satu fungsi manajemen yang sangat penting sebag tanpa fungsi ini, maka apa yang telah direncanakan dan diorganisasikan itu tak dapat direalisasikan dalam kegiatan. Perencanaan akan berjalan dengan baik apabila ditunjang oleh perencanaan yang bail pengorganisasian yang baik, dan pengawasan yang baik.

Berdasarkan hal tersebut di atas, maka dapat dikemukan bahwa pelaksanaan merupakan proses operasioanl yang mengelola sumber daya selama tindakan, memerlukan keterampilan, memotivasi kepemimpinan yang khusus serta koordinasi di antara banyak orang. Sekilas organisasi pelaksanaan tersusun, maka tugas kepemimpinan untuk menggerakan orang-orang dalam organisasi untuk bekerja secara optimal. Dalam proses ini terkandung usaha bagaimana memotivasi orang untuk bekerja dengan baik, bagaimana proses kepemimpinan yang memungkinkan pencapaian tujuan serta dapat memberikan suasana hubungan kerja

${ }^{39}$ Marno, Islam By Management Leardership, Jakarta: Lintas Pustaka Publisher, 2007, hal. 53.

40 Muhammad Faturrohman, Implemenasi Peningkatan Mutu Pendidikan Islam: Lembaga Pendidikan Islam Secara Holistik (Praktik dan Teori), Yogyakarta: Teras, 2012, hal. 189.

${ }^{41}$ Sudjana, Manajemen Program Pendidikan untuk Pendidikan Sekolah dan Pengembangan SDM, Bandung: Falah Production, 2000, hal. 20. 
yang baik, dan bagaimana mengkoodinasi orang-orang dan kegiatan-kegiatan dalam suatu organisasi sehingga dapat menghasilkan tim kerja yang harmonis.

Dalam hal ini ada beberapa faktor dapat berpengaruh terhadap keberhasilan suatu fungsi pelaksanaan atau implementasi kepemimpinan adalah sebagai berikut: a. Motivasi

Motivasi merupakan dorongan dari dalam diri seseorang untuk mencapai suatu keberhasilan atau tujuan. Pada prinsipnya orang akan termotivasi untuk mengerjakan sesutu jika: pertama, yakin akan mampu mengerjakan; Kedua, yakin akan pekerjaan tersebut memberi memberikan manfaat bagi dirinya; Ketiga, tidang sedang dibebani oleh problem pribadi atau tugas lain yang lebih penting atau mendesak; Keempat, tugas tersebut merupakan kepercayaan bagi yang bersakutan.

Motivasi adalah suatu yang pokok agar dapat menjadi dorongan seseorang untuk bekerja. Pemberian motivasi adalah agar timbul kesadaran diri. Oleh karena itu hal yang paling perlu diperhatikan adalah menumbuhkan kesadaran diri pada karyawan bahwa bekerja nerupakan suatu kebtuhan hidup. Adapun hal-hal yang perlu dimotivasi yaitu: 1) Unsur etos kerja yaitu sikap mendasar terhadap diri dan dunia yang dipancarkan hidup. Meningkatkan minat untuk terus mengembangkan diri, berlomba-lomba secara sehat untuk berprestasi mengembangkan organisasi; 2) Unsur pengetahuan dan keterampilan yaitu menjadi bekal dalam melakukan pekerjaan sehingga dapat mengatasi setiap perusahaan yang dihadapi; 3) Unsur ketaatan beribadah yaitu agar tumbuh sebuah kesadaran bahwa segala sesuatu yang dilakukan dalam bekerjaan, tak lepas dari pengurusan Allah SWT; 4) Unsur kejujuran yaitu harus dapat diyakinkan bahwa kejujuran, pekerjaan akan jauh lebih mudah, lebih sehat, dan lebih baik. ${ }^{42}$

Ada teori lain tentang motivasi dalam pekerjaan, yang harus diperhatiakn Ketua STAI Kharisma Sukabumi dalam kepemimpinan bawahannya di sebuah institusi yaitu sebagai berikut:43 1) Teori keadilan (equity), teori ini menonjolkan kenyataan bahwa motivasi seseorang mungkin dipengaruhi oleh perasaan seberapa baikkah mereka diperlakukan di dalam organisasi apabila dibandingkan orang lain. kalau orang merasa perlakuan orang-orang terhadapnya tidak sebaik perlakuan orang-orang itu terhadap orang lain yang dinggap sebanding, kemungkinan besar orang itu kurang terdorong untuk menyajikan kinerja yang baik; 2) Teori sasaran, (goal) teori didasarkan pada kepercayaan bahwa sasaran orang ditentukan oleh cara mereke berprilaku dalam pekerjaan dan jumlah upaya yang mereka gunakan. Ada indikasi bahwa memiliki sasaran yang benar-benar

42 Muhammad Faturrohman, Implemenasi Peningkatan Mutu Pendidikan Islam: Lembaga Pendidikan Islam Secara Holistik (Praktik dan Teori),...,2012, hal. 190-191.

${ }^{43}$ Hamzah B. Uno, Teori Motivasi dan Pengukurannya: Analisis di Bidang Pendidikan, Jakarta: Bumi Aksara, 2011, hal. 49. 
jelas memang membantu mendorong minat orang, dan hal itu cenderung untuk mendorong organisasi berupaya mengembangkan rencana kinerja manajemen yang lengkap.

Dalam hal ini, Purwanto mengatakan bahwa fungsi motivasi bagi manusia adalah: 1) Sebagai motor penggerak bagi manusia, ibarat bahan bakar pada kendaraan; 2) Menentukan arah perbuatan, yakni kearah perwujudan suatu ditempu untuk mencapai sebuah tujuan, dalam hal ini makin jelas tujuan, maka makin jelas puala bentangan jalan yang harus ditempuh; 3) Menyeleksi yang serasi guna mencapai tujuan dengan menyampingkan perbuatan yang tidak bermanfaat bagi tujuan. ${ }^{44}$

Dari pandangan tentang motivasi sebagaimana disebutkan di atas, semuanya di arahkan pada munculnya dorongan untuk mencapai tujuan. Jika tersebut dikaitkan dengan dorongan setiap personal dalam melakukan kegiatannya maka tujuan yang dicapai tidak dapat dilepaskan konsep apa yang dikehendaki pimpinan dalam sebuah institusi. Demikian pemaparan tersebut, STAI Kharisma Sukabumi harus memperhatikan faktor ini agar dapat mempengaruhi bawahanya dengan dasar atau cara langkah motivasi.

b. Komunikasi.

Langkah berikutnya yang harus diterapkan STAI Kharisma, yaitu komunikasi. Komunikasi adalah penyampaian suatu informasi dari seseorang kepada orang lain di mana informasi itu dapat di pahami oleh si penerima informasi tersebut. Salah satu unsur pokok pengelolaan staf adalah komunikasi, untuk menyampaikan suatu gagasan atau program yang dapat meyakinkan berbagai pihak akan pentingnya program tersebut sehingga orang lain dapat terdorong ikut mendukungnya. Komunikasi disebut efektif bila mencapai tujuan. Prinsip-prinsip yang dilakukan agar komunikasi dapat berjalan dengan efektif sebagai berikut: ${ }^{45}$ 1) Agar berfikir dan berbicara dengan jelas. Pertama, ada sesuatu yang sangat penting; 2) Kedua, Ada tujuan yang jelas; 3) Ketiga, Agar bisa penguasaan terhadap masalah; 4) Agar pemahaman proses komunikasi dan menerapkannya dengan konsisten; 5) Bisa mendapatkan empati dari komunikan (sasaran); 6) Selalu menjaga kontak mata, suara yang tidak terlalu keras atau lemah.

c. Kepemimpinan

Kepemimpinan adalah seni untuk mempengaruhi, mendorong, membimbing, mengarahkan dan menggerakan, dosen, staf, mahasiswa dan pihak lain yang terkait untuk bekerja yang berperan serta guna mencapai tujuan yang telah ditetapkan. Dalam hal ini, tentu kepemimpinan harus memperhatikan beberapa langkah dalam kepemimpinannya.

${ }^{44}$ M. Ngalim Purwanto, Psiklogi Pendidikan, Bandung: Remaja Rodakrya, 1998, hal. 71.

45 Muhammad Faturrohman, Implemenasi Peningkatan Mutu Pendidikan Islam: Lembaga Pendidikan Islam Secara Holistik (Praktik dan Teori),...,2012, hal. 192. 
Pertama, yang berkaitan dengan pendekatan terhadap kepemimpinan perguruan tinggi yaitu: ${ }^{46}$ pendekatan agen perubahan (change agents). Dalam pendekatan ini pemimpin menentukan visi organisasi/lembaga dengan jelas, serta berupaya keras untuk mewujudkannya dengan mengedepankan perubahan yang perlu dilakukan organisasi. Pendekatan tersebut lebih menekankan pada indetifikasi pemimpin perguruan tinggi akan perannya dalam memimpin organisasi, sehingga pemimpin mampu memposisikan dirinya dalam organisasi pendidikan tinggi. dalam konteks perubahan pendidikan tinggi sebaiknya pendekatan agen perubahan ini mungkin lebih fleksibel dan aplikatif untuk dapat diterapkan dalam kepemimpinan perguruan tinggi (STAI Kharisma), sudah tentu penyeimbangan diperlukan terkait dengan fokus dalam memimpin perguruan tinggi sebagai lembaga pendidikan yaitu pencapaiannya harus dilihat dalam konteks tridharma, sehingga keefetifan kepemimpinan akan berdampak pada keefetifan organisasi dalam mencapai tujuan.

Kedua, peran dan tugas kepemimpinan; kepemimpinan dilingkungan perguruan tinggi pada dasarnya berperan sebagai faktor yang yang menentukan dalam jalur pencapaian tujuan pendidikan tinggi melalui pengembangan organisasi dan aktivitas manajemen dalam mendayagunakan seluruh sumber daya pendidikan yang tersedia dalam organisasi, dengan tugas utamanya adalah melaksanakan Tridharma sebagai core bussinees perguruan tinggi, oleh karena itu, fokus kepemimpinan perguruan tinggi haruslah pada pelaksanaan tridharma yang makin efektif dan bermutu menjadikannya sebagai keunggulan kompetitif. ${ }^{47}$

Tentu dalam konteks ini, Ada empat peran utama yang harus diperhatikan kepemimpinan (STAI Kharisma) efektif, yaitu: sebagai penentu arah, agen perubahan, juru bicara, dan pelatih. Keempat peran ini secara bersama-sama merupakan pekerjaan pemimpin visioner. Keempat peran kepemimpinan ini sama pentingnya untuk mencapai keberhasilan. Dalam menajalankan peran tersebut, kepemimpinan dijalankan dengan dukungan kemampuan, sifat, dan kepribadian pemimpin untuk mempengarauhi. ${ }^{48}$

Ada beberapa hal menjadi acuan atau harus dimiliki bagi STAI kharisma yaitu kepemimpinan yang selalu berpikir kreatif, senantiasa melakukan ekperimen pemgembangan mutu akademik secara ilmiah, terencana dan sistematis, refponsif terhadap problem secara internal maupun eksternal, maupun mendorong lahirnya inisiatif bawahan, mengedepankan kemandirian, kerja sama serta memutuskan suatu hal melalui pemikiran yang matang.

46 Uhar Suharsaputra, Manajemen Pendidikan Perguruan Tinggi: Starategi menghadapi Perubahan, Bandung: PT Refika Aditama, 2015, hal. 362.

47 Uhar Suharsaputra, Manajemen Pendidikan Perguruan Tinggi: Starategi menghadapi Perubahan,...,hal. 362.

48 Syafaruddin, Kepemimpinan Pendidikan Kontemporer, Bandung: Citapustaka Media, 2013, hal. 59. 
Selain itu, kepemimpinan pada institusi perguruan tinggi (STAI Kharisma) juga senantiasa berorientasi pada kompetensi demi kemajuan perguruan tinggi yang dikelolahnya dengan menerapkan etika kepemimpinan sebagaimana dikemukan freeman dan stewart yang dikutip Nugroho, yakni mencakup: 1) Memiliki pengetahuan tentang nilai-nilai moral, mampu menjelaskan dan menerapkannya dalam kehidupan dalam kehidupan sehari-sehari; 2) Senantiasa fokus pada kepentingan institusi perguruan tinggi dari pada kepentingan individu; 3) Menemukan orang-orang berintegritas dan mengembangkan kepercayaan kepadanya. Saat ini yang lebih diperlukan adalah orang yang berintegritas dan bertanggungjawab. Bukan hanya sekedar pintar dan terampil mereka inilah yang dipercaya mampu mengembangkan organisasi saat ini dan ke depan; 4) Memelihara dan mengembangkan nilai-nilai tinggi positif organisasi kepada masyarakat dan stakeholder; 5) Mengembangkan mekanisme berbeda pendapat. Hal ini sangat diperlukan untuk mengembangkan inovasi, pengembangan kelembagaan, atau alternatif solusi organisasi. Pemimpin perlu turun ke bawah menemukan permasalahan teknis dan alternatif solusi dari lapangan.

Selain itu kepemimpinan STAI Kharisma harus memiliki kemampuan manajerial yang baik, sehingga mampu membawa unsur-unsur lembaga secara sistemik ke arah yang diinginkan sesuai dengan visi, misi dan tujuan lembaga yang dipimpinya. Pemimpin lembaga juga harus mampu mewujukan program yang berkelanjutan mengacu pada pada standar mutu yang dipersyarat. ${ }^{49}$

\section{D.PENUTUP}

Berdasarkan hasil analisis keseluruhan uraian di atas, dapat disimpulkan dari kajian kualitatif-deskriptif secara umum dapat disimpulkan bahwa imlplementasi kepemimpinan dalam peningkatan sistem penjaminan mutu internal pada Sekolah Tinggi Agama Islam Kharisma Cicurug-Sukabumi. Dalam penelitian ini ditemukan beberapa hal sebagaimana berikut:

Pertama, hambatan-hambatan terkait dalam peningkatan mutu internal yakni; Dana Terbatas, sarana dan prasarana tidak terpenuhi, lemahnya sumber daya manusia, belum optimalnya kinerja tenaga pendidik dan kependidikan, manajemen perguruan tinggi belum tertata dengan baik dan rendahnya mutu lulusan perguruan tinggi; Kedua, upaya ketua STAI Kharisma Sukabumi di antaranya yaitu: memperkuat sumber daya tenaga kependidikan, Pendidikan dan pelatihan dalam pengelolaan penjaminan mutu, pendidikan dan pelatihan dalam pengelolaan penjaminan mutu, Memberikan suport kelompok kerja meraih mutu, dan mensosialisasikan teknik dalam perbaikan mutu; Ketiga, Implementasi kepemimpinan dalam peningkatan sistem penjaminanan mutu internal belum

${ }^{49}$ Hidayati, “Manajemen Pendidikan Standar, Pendidikan, tenaga Kependidikan dan Mutu Pendidikan", Jurnal Ta'lim, Vol. 21 (2014): 43. 
dijalankan secara baik karena masih lemahnya komitmen birokrat dan pengelola kepemimpinan untuk mencapai keunggulan mutu. Selain itu kurangnya kecakapan pengelola STAI Kharisma Cicurug-Sukabumi dengan spektrum tugas maupun masalah pendidikan yang semakin kompleks. 


\section{DAFTAR PUSTAKA}

Abseni, el al. Implementasi SIstem Penjaminan Mutu Internal Perguruan Tinggi (Suatu Studi Tentang Standar Operasinal Prosedur) di Politeknik Negeri Sambas, jurnal Tesis PMIS-UNTAN-PSIAN, Pontianak, 2013.

Attabik, Ali. Kamus Inggris Indonesia Arab, Yogyakarta: Mukti Karya Grafika, 2003.

Aziz, Safrudin. Manajemen Mutu Perguruan Tingg: Koreksi dan Implementasi, Yogyakarta: Gava Media, 2016.

Badan Penjaminan Mutu Akademik (BPMA) UI, Pedoman Penjaminan Mutu Akademik Universitas Indonesia: Penelitian, Pengabdian dan Pelayanan Kepada Masyarakat, Depok: BPMA UI, 2007.

Baharuddin, Kajian Konsep Manajemen Mutu Pendidikan Berbasis Qur'an Pendekatan Tafsir Maudhu'i, Laporan Penelitian, Malang: Fakultas Islam Tarbiyah dan Keguruan UIN Maulana Malik Ibrahim Malam, 2015.

Bashith, Abdul.. Penjaminan Mutu di Perguruan Tinggi Islam, konsepsi, Interpretasi, dan Aksi, Malang: UIN Maliki Press, 2016.

Burhanuddin, Manajemen Sumber Daya Manusi, Dalam Manajemen Pendidikan Analisis Subtabtif dan Aplikasinya dalam Institusi Pendidikan, Malang: Universitas Negeri Malang, 2003.

Danim, Sudarmawan. Visi Baru Manajemen Sekolah: dari Unit Birokrasi ke Lembaga Akademik, Jakrta:PT Bumi Aksara, 2006.

Danim, Sudarwan. Kepemimpinan Pendidikan: Kepemimpinan jenius $(I Q+E Q)$ Etika, Perilaku Motivasional, Bandung: Al-Fabeta, 2012.

Dzaujak, Ahmad. Petunjuk Penigkatan Mutu Pendidikan di sekolah Dasar, Jakarta, Depdikbud, 1996.

Fatah, Nanang. Landasan Manajemen pendidikan, Bandung: Remaja Rosda karya, 1999.

Fathorrohman, Kompetensi Pedagogik, Profesional, Kepribadian Dan Kompetensi Sosialdosen, dalam Jurnal AKADEMIKA; Vol. 15. No.1 Tahun 2017.

Febriani, Nur Arfiyah, et.al, Panduan Penyusunan Tesis dan Disertasi, Jakarta: Program Pascasarjana Institut PTIQ, 2017.

Fitrah, Muh,. et.al. "Urgensi Sistem Penjaminan Mutu Internal Terhadap Peningkatan Mutu Perguruan Tinggi", dalam Jurnal Penjaminan Mutu Lembaga Pejaminan Mutu Institut Hindu, Dharma Negeri Denpasar, Vol. 4 Nomor 1 Tahun 2018.

Hariyani, Mimi. “Analisis Kompetensi Profesional Dosen Fakultas Tarbiyah Dan Keguruan Uin Sultan Syarif Kasim Riau, dalam Jurnal Pesona Dasar, Vol. 1 Tahun 2017.

Heni, "Akuntabilitas Mutu Pelayanan Perguruan Tinggi," dalam Jurnal Pendidikan dan Pembelajaran, Vol. 18. No. 1 Tahun, 2011.

Hidayati, "Manajemen Pendidikan Standar, Pendidikan, tenaga Kependidikan dan Mutu Pendidikan, “ dalam Jurnal Ta'lim, Vol. 21 tahun 2014. 
Idris, "Penelitian dan Pengabdian Masyarakat pada Perguruan Tinggi," dalam Jurnal Pendidikan dan Kebudayaan, Vol. 1 No. 3 Tahun 2010.

Indrajit, Eko dan Jokopranoto, Manajemen Perguruan Tinggi Modern, Yogyakarta: Andi, 2005.

Kartika, Ika. "Strategi, Pengembangan Penelitian di Perguruan tinggi Swasta," Media Nusantara, No. 16 Tahun, 2012.

Kayo, RB. Khatib Pahlawan . Kepemimpinan Islam dan Dakwah, Jakarta: AMZAH, 2005.

Kolter, Philip dan Alan R. Andresean, Strategi Pemasaran Untuk Organisasi Nirlaba. Penerj. Ora Enika, Yogyakarta: Gajah Mada University, 1996.

Komariyah, Aan dan Triatna, Cepi. Visioanary Leadership, Menuju Sekolah Efektif, Jakarta: Bumi Aksara, 2008.

Lestari, Indriana. "Pengaruh Sistem Penjaminan Mutu Internal Dan Sistem Manajemen ISO 9001:2008 Terhadap Kinerja Universitas Katolik Indonesia Atma Jaya Jakart." TESIS. Jakarta: Fakultas Ilmu Sosiall Dan Ilmu Politik Progaram Pasca Sarjana, 2012.

Listyo, Sugeng. Manajemen Pengembangan Mutu sekolah, Malang: UIN Malang Press, 2008.

Mahmud, Marzuki. Manajemen Mutu Perguruan tinggi, Jakarta, PT Grafindo Persada, 2012.

Mantja, W. Manajemen Pendidikan dan Supervisi Pengajaran, Malang: Wineka Media, 2002.

Marno, Islam By Management and Leadership, Jakarta: lintas Pustaka, 2007.

Minhaji, Akh. Tradisi Akademik di Perguruan Tinggi, Yogyakarta: Suka Press, 2013.

Morgan, Collin. Pengembangan Profesional Untuk Manajemen Pendidikan, Jakarta: Grasindo, 2004.

Mulyadi, Kepemimpinan Kepala Madrasah dalam Budaya Mutu, Jakarta: Balitbang dan Diklat Kementerian Agama RI, 2010.

Mulyadi. Kepemimpinan Kepala Madrasah dalam Budaya Mutu, Jakarta: Balitbang dan Diklat Kementerian Agama RI, 2010.

Mulyasa, Dedi. Pendidikan Bermutu dan Berdaya Saing, Bandung: Remaja Rosdakarya, 2012.

Mulyasa, E. Menjadi Kepala Sekolah Profesional dalam Konteks Menyukseskan MBS dan KBK, Bandung: Remaja Rosdakarya, 2004.

Mulyasana, Dedi. Pendidikan bermutu dan Berdaya saing, Bandung: Remaja Rosdakarya, 2012.

Mulyono, Manajemen, Administrasi dan Organisasi Pendidikan, Yogyakarta: Ar-Ruzz Media, 2008.

Naisabit, John dan Aburdene, Patricia. Megatrend 2000: Sepuluh Arah Baru Untuk Tahun 1990 an. Penerj. Budijanto, Jakarta: Bina Rupa Aksara, 1990.

Nasution, M. Nur. Manajemen Mutu terpadu, Bogor: GI, 2005.

Nazir, Moh. Metode Penelitian, Bogor: Ghalia Indonesia, 2013. 
Prihantoro, Rudy. Konsep Pengendalian Mutu, Bandung: Rosdakarya, 2012.

Purwanto, M. Ngalim Psikologi Pendidikan, Bandung: Remaja Rodakrya, 1998.

Qomar, Mujami. Manajemen Pendidikan Islam: Starategi Pengelolaan Pendidikan Islam, Jakarta: Erlangga, 2008.

R. Eko Indrajit dan Djokokopranoto, R. Manajemen Perguruan Tinggi Modern, Yogyakarta: Andi, 2006.

Rangkuti, Fredy. Tehnik Mengubah Kasus Bisnis Analisis SWOT, Jakarta: Gramedia, 2014.

Razak, Yusran. dkk, "Kepemimpinan, Kinerja Dosen Dalam Peningkatan Mutu Pendidikan Perguruan Tinggi." dalam Jurnal TANZIM; Penelitian Manajemen Pendidikan, Vol.1 No.2 Tahun 2016.

Rusman, Manajemen Kurikulum, Jakarta: Rajagrafindo, 2009.

Saihu, "Implementasi Manajemen Balanced Scorecard di Pondok Pesantren Jam'iyyah Islamiyyah Tangerang Selatan, Mumtaz, Vol. 3, No. 1 (2019): 1-22.

Sallis, Edwar. Total Quality Management In education, diterjemahkan oleh Ahmad AliRiyadi, Yogyakarta: Ircisod, 2006.

Sani, Ridwan Abdullah Penjamin Mutu Sekolah, Jakarta: PT Bumi Aksara, 2015.

Sarnoto, Ahmad Zain. "Urgensi Peningkatan Mutu Dalam Pengelolaan Pesantren dalam Era Global." dalam Jurnal EDUCARE, Vol. 3 No. 3 Tahun 2013.

Siram, Reddy. "Manajemen Penjaminan Mutu Layanan Akademik Perguruan Tinggi." Dalam Jurnal Ilmu Pendidikan, Vol. 21 No. 1 Tahun 2015.

Soemanto dan Soetopo, Kepemimpinan dalam Pendidikan, Surabaya: Usaha Nasional 1998.

Sudin, "Pengabdian Kepada Masyarakat Bagi Perguruan Tinggi Agama Islam, dalam Jurnal Aplikasia, Vol. V No. 2 Tahun 2004.

Sudiyono, Manajemen Pendidikan Tinggi, Jakarta: Rineka Cipta, 2004.

Sudjana, Manajemen Program Pendidikan untuk Pendidikan Sekolah dan Pengembangan SDM, Bandung: Falah Production, 2000.

Suharsaputra, Uhar. Manajemen Pendidikan Perguruan Tinggi: Strategi Menghadapi Perubahan, Bandung: PT Refika Aditama, 2015.

Shunhaji, Ahkmad. Implementasi Pendidikan Agama di Sekolah Katolik Blitar dan Dampaknya Terhadap Interaksi Sosial, Yogyakarta: Aynat Publishing, 2017.

Suryanigsih, Tutut dan Imron, Ali. Komitmen Kepemimpinan Dalam Implementasi Sistem Penjaminan Mutu Akademik Perguruan Tinggi: Studi Kasus Pada STKIP PGRI Tulungagung, “dalam Jurnal Pejaminan Mutu, Vol. 05 No. 1 Tahun 2019.

Susilo, Willy. Starategi Menegakkan Mutu Pendidikan Tinggi Berbasis KKNI, Yogyakarta: ANDI OFFSET, 2018.

Sutopo, Administrasi Manajemen dan Organisasi, Jakarta: Lemabaga Administrasi Negara republik Indonesia, 1999.

Sutrisno, Pendidikan Islam yang Menghidupkan: Studi Kritis Terhadap Pemikiran Fazlur Rahman, Yogyakarta: Kota Kembang, 2006. 
Suwignyo, Agus. Pendidikan Tinggi dan Goncangan Perubahan, Yoyakatarta: Putaska Pelajar, 2008.

Syafaruddin, Kepemimpinan Pendidikan Kontemporer, Bandung: Citapustaka Media, 2013.

Syuaibah, Muhammad. "Kepemimpinan dalam Sistem Penjaminan Mutu Pendidikan Tinggi." dalam Jurnal Widya, Vol. 2 No. 3 Tahun 2014.

Tabroni, The Spritual Leadership, Malang: UMM Press, 2005.

Tampubolon, Mutu Perguruan Tinggi, medan: Ikip Medan, 1995.

Tjiptono, Fandi. Perspektif Manajemen dan Pemasaran Kontemporer, Yogyakarta: Andi, 2010

Tunggal, Amin Widjaja. Manajemen Suatu Pengatar, Jakarta: PT Rineka Cipta, 2002.

Umaedi, Manajemen Mutu Berbasis Sekolah, Jakarta: Pendidikan Dasar dan Menengah Umum, 1999.

UU RI Nomor 20 Tahun 2003 Tentang Sisdiknas, Semarang: Aneka Ilmu, 2003.

Winardi, Asas-Asas Manajemen, Bandung: Anggota IKAPI, 1981.

Yamit, Zulian. manajemen Kualitas Produk dan Jasa, Yogyakarta: Ekonisia, 2004.

Zain, Nur. Gerakan Bermutu Pendidikan: Teori dan Aplikasi, Jogjakarta: Ar-Ruzz Media, 2016.

Hasil Observasi di Kampus STAI Kharisma Cicurug-Sukabumi, Tanggal 14 September 2019.

Hasil Wawancara Dengan Bapak Ujang Saefullah, Ketua STAI Kharisma CicurugSukabumi Tanggal 15 September 2019.

Hasil Wawancara Dengan Isni Layla, Mahasiswa STAI Kharisma CicurugSukabumi Tanggal 15 September 2019.

Hasil Wawancara Dengan Nur Isna Saqinah, Mahasiswa STAI Kharisma CicurugSukabumi Tanggal 14 September 2019

Hasil Wawancara Dengan Samsul, Mahasiswa STAI Kharisma Cicurug-Sukabumi Tanggal 15 September 2019.

Hasil Wawancara Dengan Siti Ayi Syuroh, Mahasiswa STAI Kharisma CicurugSukabumi Tanggal 15 September 2019

.Hasil Wawancara Dengan Latifatul Maula, Mahasiswa STAI Kharisma CicurugSukabumi Tanggal 15 September 2019. 